\title{
DYNAMIC ANALYSIS AND COMPARATIVE STUDY OF PLAN IRREGULAR (C-SHAPED) BUILDING WITH DIFFERENT TYPES OF BRACING SYSTEM
}

\author{
Abdul Wasey Abdul Wahab \\ M.Tech Student \\ Department of Civil Engineering \\ Shri Guru Govind Singhji Institute of Engineering \\ and Technology, Nanded
}

\author{
Dr. P. B. Ullagaddi \\ Professor \\ Department of Civil engineering \\ Shri Guru Govind Singhji Institute of Engineering \\ and Technology, Nanded
}

\begin{abstract}
When the multi-storied buildings are constructed a suitable care should be taken while designing, as they are subjected to lateral forces. The behaviour of multi-story building depends upon either in plan or in vertical direction i.e, elevation, is considered as one of the main causes of failure during earthquakes. Thus irregular structures, especially the structures which are located in seismic zones are required a special attention during analysis and design of structure. In this study Plan irregular (C-shaped building) is considered to carry out study. Bracing system is installed to provide strength against lateral loading and the behaviour of the structure in terms of base shear, story drift, stiffness and the lateral displacements are observed. Three different types of bracings $X, V$ and Diagonal are installed in the structure. Total 4 models are analysed for 7 story height level, 4 Models are computed to determine the performance of the structure. One MRF and three models with different bracing system. And the best suitable bracing system for this study. The method used for this study is response spectrum method, to perform dynamic analysis of the structure.
\end{abstract}

Key Words: Plan Irregular Building, Dynamic Analysis, Bracing System

\section{INTRODUCTION}

Generally, the structures are classified as low rise and high rise buildings depending up on the height of the structure. Low rise structures are generally subjected to dead load and live loads, and when it comes to high rise structures, the structures are subjected to dead load, live load as well as lateral loads, which involves earthquake loads and wind loads. Hence the effect of these loads should be given a proper attention against these lateral loads. So that the structure should behave in a proper manner to maintain the stability of structure, and a proper care should be taken while designing. Generally bracing system and shear wall system is provided to with stand against lateral loading. Following some researches are given that are carried out by researchers.

Anusha K, Raghu K May-2018 studied the Analysis of multi storied Braced Frame Structure with various parameters as Per Indian-Standards, for the study a G+15 storey building, and concluded that the displacement of the structure is reduced after the installation of bracing method. Kanungo et al., 7(12): December, 2018 has studied the analysis of G+20 storey building with $\mathrm{X}$-type bracing model and without bracing model, and compared the results of the models in different seismic zones. He concluded that the steel bracedsystem has not only increased the displacement capacity of reinforced concrete-structures, as well as the lateral strength and stiffness capacity of the structures by increasing its shear capacity. Dia Eddin et.al. (2017) studied Steel frame with different varying heights of building. Four different models are with the different stories as 4 storey, 8 storey, 12 storey and16 storey. VBS, XBS, Knee bracing system, and Zipper bracing system (ZBS) bracing systems are provided. The bracing frame system shows lower roof displacement as compared to un-braced frame system.

In this study plan irregular (C-shaped) building is considered to analyse and different bracing systems are installed to act against lateral loading. When the lateral forces acts on the structure the structural behaviour of the building changes, and lateral displacement takes place. 


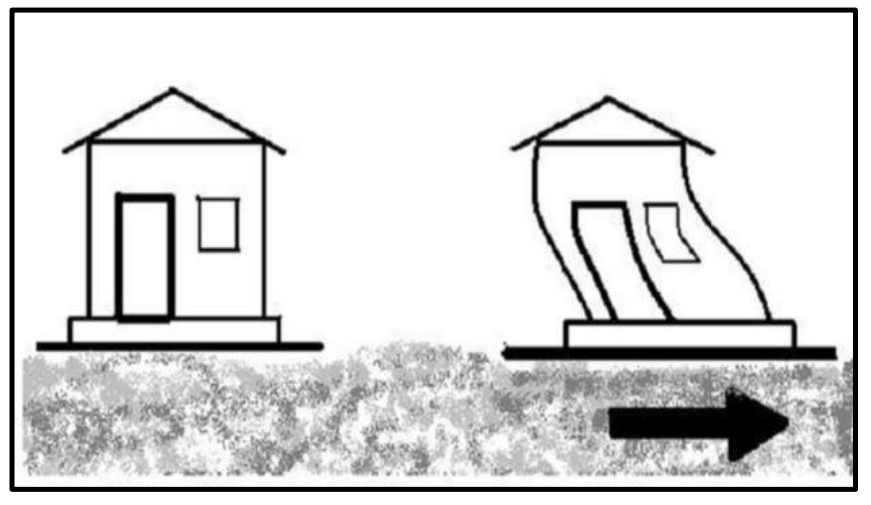

Fig : Effect of shaking due to Earthquake load

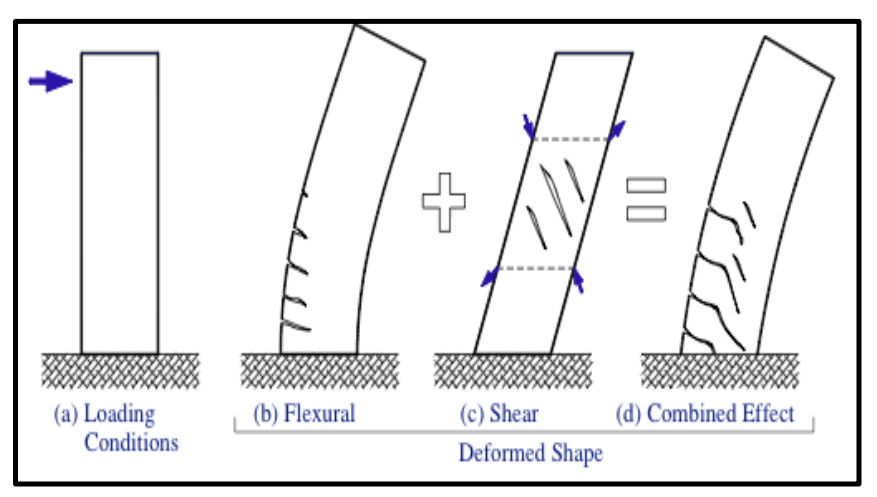

Fig : Effect of Wind Load on building

\subsection{Lateral Force Resisting system}

$>$ Moment Resisting Frame (MRF)

$>$ Shear Wall System

$>$ Bracing System

\subsection{Steel Bracing systems}

Braced-frames generally eliminate the columns and beam bending moment factors and thus increases the capacity of the fixed frame in actions. By the addition of truss-like members such as diagonals, members (between the floor systems) this can be become and gain good efficiency effectively. These diagonal members carry the lateral loads and transfers the axial loads to the vertical member i.e. columns, which is an effective structural system.

\subsection{Objectives}

1. To study the Dynamic response of plan irregular building subjected to lateral loads.

2. To find out the Dynamic response of plan irregular building with respect to different bracing systems.
3. Response and effect of different bracings on building model with respect to different loads.

4. To study the effect of different parameters i.e. Base Shear, story drift, lateral displacement etc. on building model.

5. To find out the suitable bracing type against the loading.

\section{METHODOLOGY}

In the present study, an attempt was made to analyse the structural behaviour of a 7 storied, plan irregular (C-Shaped) RCC MRF building using different bracing patterns as X, V, and Diagonal bracing systems are used. First, the MRF buildings are analysed based on IS 1893 part 1, these models were analysed by static analysis, response spectrum analysis to determine Base shear, lateral displacement, storey drift. After the bracing system is provided and the results of MRF and braced frames are compared to each other.

\subsection{Structural Configuration and Data}

The following data were considered during the analysis.

\begin{tabular}{|c|c|}
\hline Structural detail \\
\hline Storey height & $\begin{array}{c}3.2 \mathrm{mts} \text { at Ground } \\
\text { Floor \& Remaining } \\
\text { Floors. }\end{array}$ \\
\hline Plan Configuration & $\begin{array}{c}\text { Plan Irregular (C- } \\
\text { shaped) }\end{array}$ \\
\hline Base & $16 \mathrm{~m}$ \\
\hline Length & $24 \mathrm{~m}$ \\
\hline $\begin{array}{c}\text { No. Of Story of the } \\
\text { building }\end{array}$ & 7 Story \\
\hline Slab Thickness & $0.125 \mathrm{~m}$ \\
\hline Wall Thickness & $0.23 \mathrm{~m}$ Outer wall \\
\hline & $0.15 \mathrm{~m}$ Inner wall \\
\hline
\end{tabular}

\begin{tabular}{|c|c|}
\hline \multicolumn{2}{|c|}{ Loading Detail } \\
\hline D L & IS 875 Part 1 \\
\hline & F.F $=1.5 \mathrm{KN} / \mathrm{m}^{2}$ \\
\hline & \\
\hline L L & IS 875 Part 2 \\
\hline & L.L $=2$ and $3 \mathrm{KN} / \mathrm{m}^{2}$ \\
\hline
\end{tabular}


International Journal of Engineering Applied Sciences and Technology, 2021

Vol. 6, Issue 3, ISSN No. 2455-2143, Pages 96-102

Published Online July 2021 in IJEAST (http://www.ijeast.com)

\begin{tabular}{|c|c|}
\hline \multicolumn{2}{|c|}{ Earthquake Data } \\
\hline IS Code & IS 1893 Part $1: 2016$ \\
\hline Seismic Zone & 4 \\
\hline Importance Factor (I) & 1 \\
\hline Response Reduction Factor & 5 \\
\hline Soil Type & II \\
\hline
\end{tabular}

\begin{tabular}{|c|c|}
\hline \multicolumn{2}{|c|}{ Wind Data } \\
\hline IS Code & IS 875 Part 3 \\
\hline $\mathrm{V}_{\mathrm{b}}$ & $47 \mathrm{~m} / \mathrm{sec}$ \\
\hline K1 & 1 \\
\hline Terrain Category & 3 \\
\hline K3 & 1 \\
\hline
\end{tabular}

\subsection{Structural Modelling and analytical work}

Total 4 models are prepared for this study. Etabs software is used in this study. 4 models for 7 storey height level one MRF and other Three are braced frames.

Following figures shows the models prepared in Etabs software.

Total 4 models are prepared in Etabs software as follows:
1. $\mathrm{MRF}$
2. $\mathrm{XBs}$
3. VBs
4. DBs

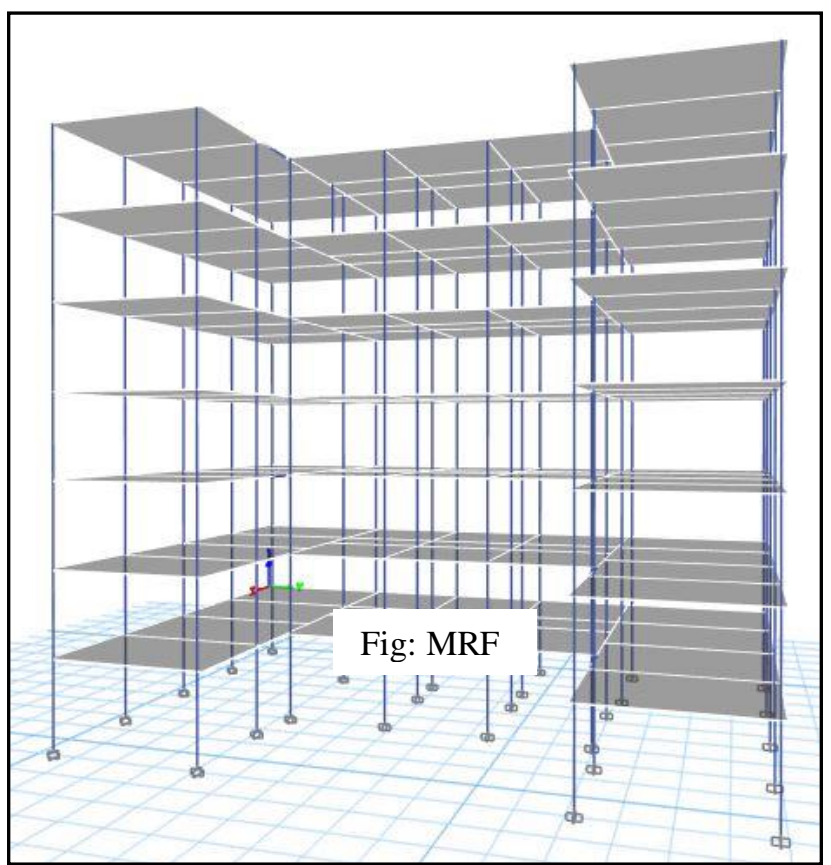

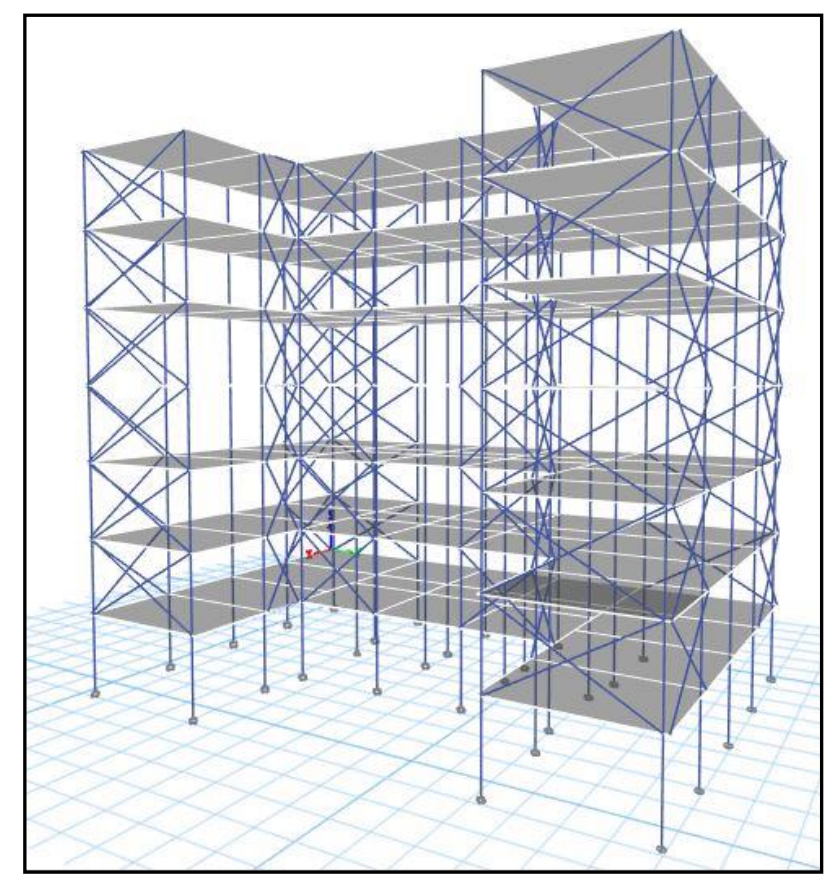

Fig: XBs

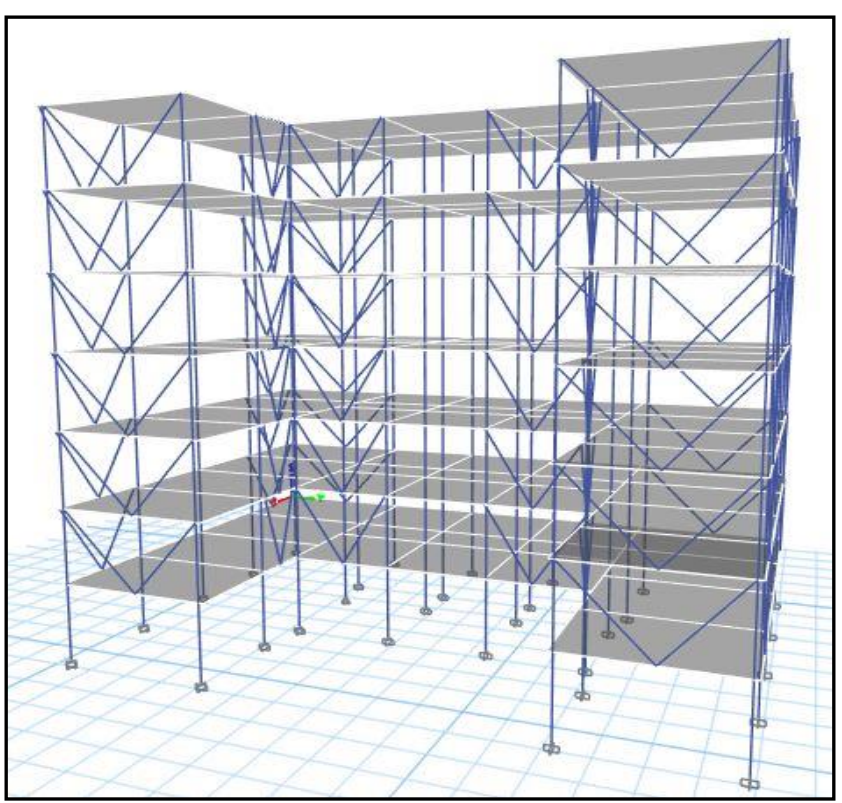

Fig: VBs 


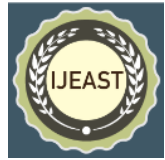

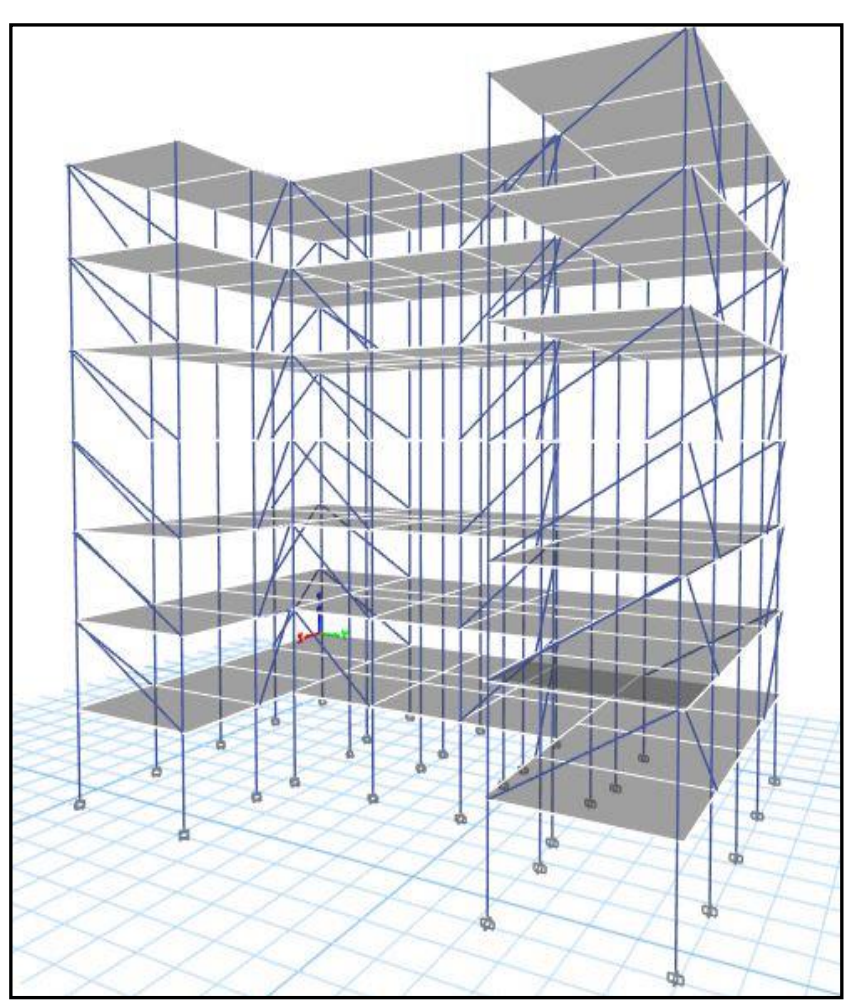

Fig: DBs

These four models shows the buildings for 7 story buildings only.

\section{RESULTS AND DISCUSSION}

All models are analysed by taking considerations of IS 456:2000 and IS 1893 (Part 1): 2016 and IS 13920 : 2016 and the results are compared.

The Results are observed and compared in terms of Base shear, story drift, lateral displacement and stiffness of the structure.

\subsection{Base shear}

Base shear is an estimate of the maximum expected lateral force that will occur at the base of the structure due to seismic ground motion.

\begin{tabular}{|c|c|c|}
\hline \multicolumn{2}{|c|}{$\begin{array}{c}\text { \% of increase in base shear due to bracing } \\
\text { system in X-Direction }\end{array}$} \\
\hline & \multicolumn{2}{|c|}{ 7 Storey Building } \\
\cline { 2 - 3 } & Static & Dynamic \\
\hline $\mathrm{XBs}$ & $0.97 \%$ & $0.43 \%$ \\
\hline $\mathrm{VBs}$ & $0.73 \%$ & $0.32 \%$ \\
\hline
\end{tabular}

\begin{tabular}{|c|c|c|}
\hline DBs & $0.61 \%$ & $0.21 \%$ \\
\hline \multirow{2}{*}{$\begin{array}{c}\text { \% of increase in base shear due to bracing } \\
\text { system in Y-Direction }\end{array}$} \\
\hline & \multicolumn{2}{|c|}{ 7 Storey Building } \\
\cline { 2 - 3 } & Static & Dynamic \\
\hline XBs & $0.97 \%$ & $0.36 \%$ \\
\hline VBs & $0.73 \%$ & $0.13 \%$ \\
\hline DBs & $0.61 \%$ & $0.14 \%$ \\
\hline
\end{tabular}

$\%$ of increase in base shear due to bracing system in XDirection

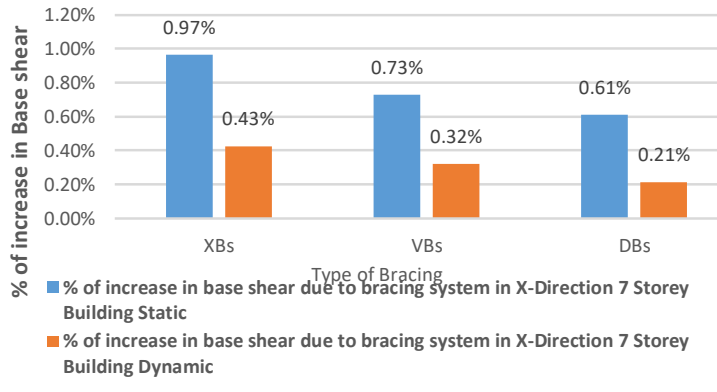

$\%$ of increase in base shear due to bracing system in $\mathrm{Y}$ Direction

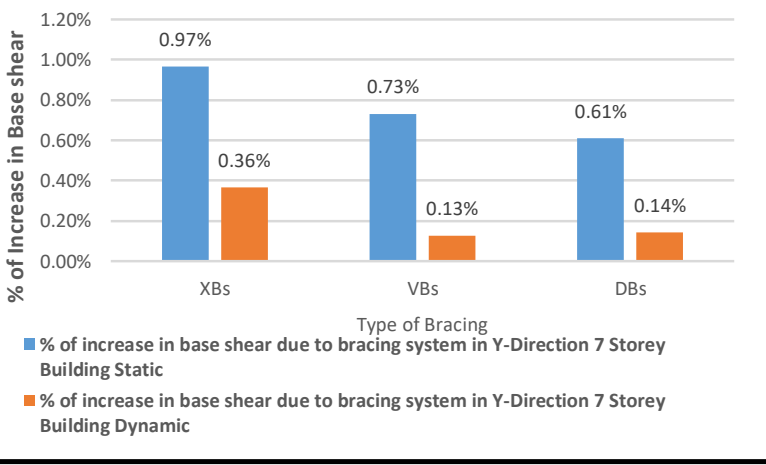

The base shear of all structures are observed and it is find that the base shear is increases as the height of the structure increases.

\subsection{Lateral displacement}

Lateral displacement is the absolute value of displacement i.e. at the top story due to action of the lateral forces. Following results are observed. 
International Journal of Engineering Applied Sciences and Technology, 2021

Vol. 6, Issue 3, ISSN No. 2455-2143, Pages 96-102

Published Online July 2021 in IJEAST (http://www.ijeast.com)

\begin{tabular}{|c|c|c|c|c|}
\hline \multicolumn{5}{|c|}{ STORY DISPLACEMENT FOR 7 STORY } \\
\hline & MFR & XBs & VBs & DBs \\
\hline Static X & 129.182 & 43.27 & 51.128 & 48.831 \\
\hline Static Y & 66.149 & 20.939 & 24.279 & 26.019 \\
\hline $\begin{array}{c}\text { Dynamic } \\
\text { X }\end{array}$ & 162.445 & 49.363 & 59.086 & 56.602 \\
\hline $\begin{array}{c}\text { Dynamic } \\
\text { Y }\end{array}$ & 82.981 & 25.815 & 30.183 & 32.506 \\
\hline
\end{tabular}

By introducing the Different bracing system to frame buildings the total displacement of buildings reduces depends upon the type of brace and stiffness.

\begin{tabular}{|c|c|c|c|c|}
\hline \% of increase in Displacement Due to Dynamic \\
loading \\
\hline & MFR & XBs & VBs & DBs \\
\hline X-Direction & $26 \%$ & $14 \%$ & $16 \%$ & $16 \%$ \\
\hline Y-Direction & $25 \%$ & $23 \%$ & $24 \%$ & $25 \%$ \\
\hline
\end{tabular}

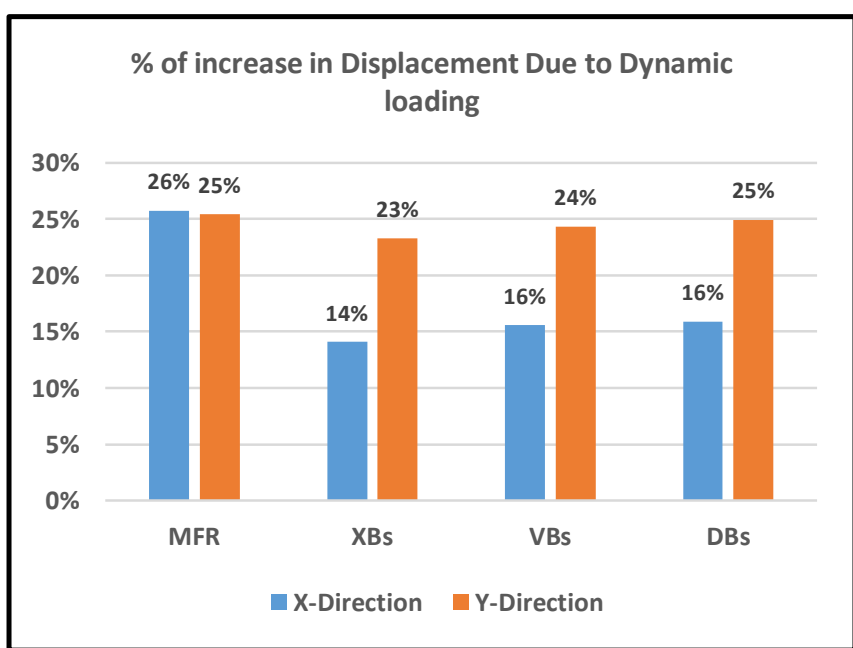

By comparing the results of all buildings, it is found that as the height of the structure increases the effect of lateral forces also increases, and the lateral displacement is also increases. According to IS 456:2000 the maximum permissible lateral displacement of building $=\mathrm{H} / 500$

Where $\mathrm{H}=$ Total Height of the building.

Some Values of lateral displacements are under limit as specified in above criteria, and in some cases this specified limit is not satisfied So, it is suggested that the Lateral Displacement of building should also be check if the storey drift for all stories will be under the permissible limit Specified in IS 1893 Part 1.

\subsection{Story Drift}

Story drift is the difference of displacements between two consecutive stories. This displacement is observed by the action of lateral forces.

\begin{tabular}{|c|c|c|c|c|}
\hline $\begin{array}{c}\text { 7 Story } \\
\text { building }\end{array}$ & MRF & $\begin{array}{c}\text { X- } \\
\text { BRACED }\end{array}$ & $\begin{array}{c}\text { V- } \\
\text { BRACED }\end{array}$ & DIAGONAL \\
\hline BASE & 0 & 0 & 0 & 0 \\
\hline Story 1 & 23.452 & 3.629 & 8.507 & 5.8 \\
\hline Story 2 & 30.173 & 4.743 & 6.805 & 6.811 \\
\hline Story 3 & 25.891 & 4.975 & 6.472 & 6.551 \\
\hline Story 4 & 20.534 & 4.867 & 6.037 & 6.005 \\
\hline Story 5 & 15.04 & 4.522 & 5.391 & 5.235 \\
\hline Story 6 & 9.553 & 4.041 & 4.635 & 4.336 \\
\hline Story 7 & 4.539 & 3.466 & 3.812 & 3.373 \\
\hline
\end{tabular}

Storey drift in X-Direction

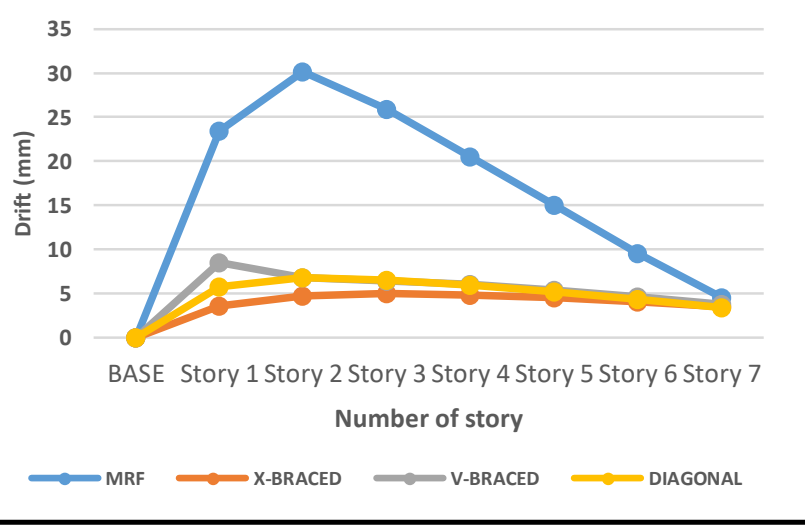

\begin{tabular}{|c|c|c|c|c|}
\hline $\begin{array}{c}7 \text { Story } \\
\text { buildin } \\
\text { g }\end{array}$ & MRF & $\begin{array}{c}\text { X- } \\
\text { BRACE } \\
\text { D }\end{array}$ & $\begin{array}{c}\text { V- } \\
\text { BRACE } \\
\text { D }\end{array}$ & $\begin{array}{c}\text { DIAGONA } \\
\text { L }\end{array}$ \\
\hline BASE & 0 & 0 & 0 & 0 \\
\hline Story 1 & 9.476 & 6.5 & 6.487 & 6.976 \\
\hline Story 2 & 14.939 & 3.926 & 4.522 & 5.622 \\
\hline Story 3 & 13.853 & 3.226 & 3.771 & 4.642 \\
\hline Story 4 & 11.27 & 3.021 & 3.463 & 4.025 \\
\hline Story 5 & 8.349 & 2.689 & 3.041 & 3.316 \\
\hline Story 6 & 5.406 & 2.287 & 2.555 & 2.554 \\
\hline Story 7 & 2.856 & 1.844 & 2.045 & 1.794 \\
\hline
\end{tabular}




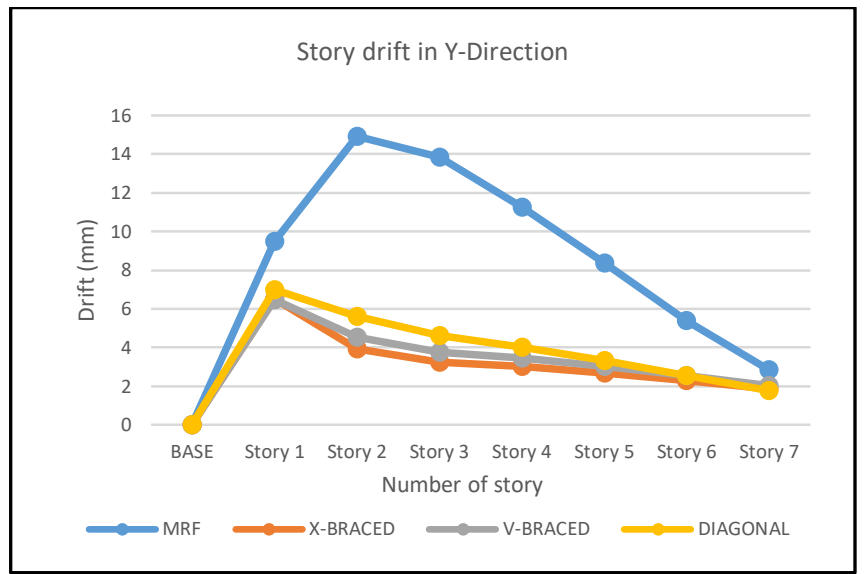

As per IS 1893 part 1 , the story drift of any story is limited to $0.004 \mathrm{x}$ Clear height of the story (Floor to floor height) for each story. The story drift for dynamic analysis is always more than the drift of static analysis.

The story drift for $\mathrm{X}$ direction is always more, because the stiffness of the structure is less in $\mathrm{X}$ direction as compare to $\mathrm{Y}$ direction.

The story drift for all story are under described limit by IS 1893 part 1 when the bracings are installed.

\subsection{Story Stiffness}

Stiffness is the term refers to the rigidity of the Structure, which tends to resist the deflection or displacement of structure.

Total Stiffness at Base For 7 Story Building

\begin{tabular}{|c|c|c|c|c|}
\hline & Static X & Static Y & $\begin{array}{c}\text { Dynamic } \\
\text { X }\end{array}$ & $\begin{array}{c}\text { Dynamic } \\
\text { Y }\end{array}$ \\
\hline MRF & 603500.8 & 1146630.1 & 627270.9 & 1216248.1 \\
\hline XBs & 2587128.5 & 3140016.1 & 2657181.9 & 3243949.0 \\
\hline VBs & 1742702.1 & 2798130.6 & 1828759.8 & 2895751.2 \\
\hline DBs & 1886343.5 & 2443939.6 & 1967223.3 & 2540414.8 \\
\hline
\end{tabular}

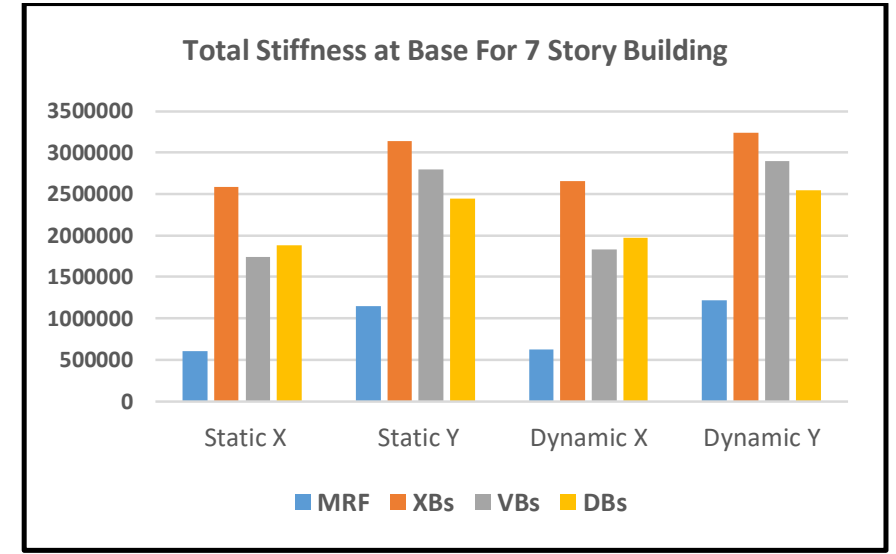

Due to the dynamic analysis the increase in total stiffness is observed at the base of structure. So the percentage of increase in stiffness is given in following table.

\begin{tabular}{|c|c|c|}
\hline \multicolumn{3}{|c|}{ \% of increase in 7 Story Building } \\
\hline & $\begin{array}{c}\text { X- } \\
\text { Direction }\end{array}$ & $\begin{array}{c}\text { Y- } \\
\text { Direction }\end{array}$ \\
\hline MRF & $4 \%$ & $6 \%$ \\
\hline XBs & $3 \%$ & $3 \%$ \\
\hline VBs & $5 \%$ & $3 \%$ \\
\hline DBs & $4 \%$ & $4 \%$ \\
\hline
\end{tabular}

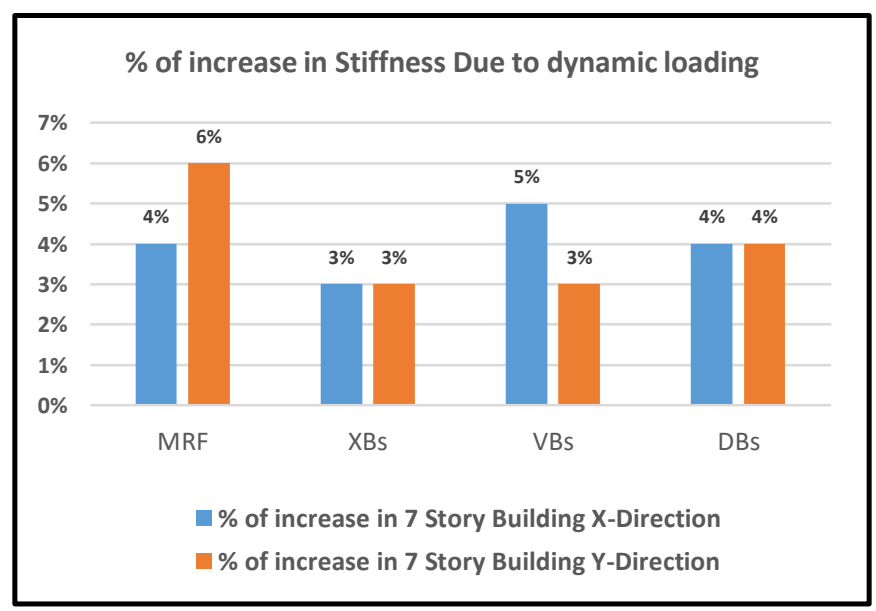

\section{CONCLUSION}

From this study different parameters are observed as per analysis results are obtained, and the following conclusions are made.

1. The results of Seismic parameters are always higher for dynamic analysis.

2. The base shear is always greater for braced frame structures. 
3. The base shear of Dynamic analysis is always greater, as stated in IS 1893 (Part 1) : 2016.

4. The behaviour of structures with varying storey are not same.

5. The Storey drift for braced frames are under the limitation specified in IS 1893 (Part 1) : 2016, except some stories, where the amount of bracing should be introduce.

6. The Storey Drift is always less for braced frames

7. The Storey Drift is Observed smaller at the top, and maximum at above $2^{\text {nd }}$ storey of the structure for each storey level.

8. The X-Braced model is always proves the best suitable bracing system, but from economical point of view Diagonal bracing is also allowable up to some extent.

\section{REFERENCES}

1) Anusha K, et.al, "Analysis of Braced Frame Multi Storied Structure with Different Angles as Per Indian Standards' 'International Research Journal of Engineering and Technology (IRJET), Volume: 05 Issue: 05 | May-2018.

2) B. Preethil et.al., "Comparative Study of different Bracing Patterns for different Plan Irregularities of the Buildings" Journal of Civil Engineering and Environmental Technology, Volume 2, Number 14; July- September, 2015.

3) Karthik. K. M et.al, "Effect Of Steel Bracing On Vertically Irregular R.C.C Building Frames Under Seismic Loads", International Journal of Research in Engineering and Technology, Volume: 04 Issue: 06 | June-2015.

4) Rabi Akhtar Et.Al, Study Of Comparison Between Static And Dynamic Analysis Subjected To Wind And Earthquake Load, International Research Journal of Engineering and Technology (IRJET) Volume: 04 Issue: 07 | July -2017.

5) Saurabh Kanungo, et.al, "Analysis Of A Tall Structure With X-Type Bracings Considering Seismic Load Using Analysis Tool Stadd.Pro, International Journal Of Engineering Sciences \& Research Technology, 7(12): December, 2018.

6) Siva Naveen Ea,d et.al, " Analysis of Irregular Structures under Earthquake Loads" Science Direct Procedia Structural Integrity 14 (2019) 806-819.

7) Rabi Akhtar et.al, "Study Of Comparison Between Static And Dynamic Analysis Subjected To Wind And Earthquake Load", International Research Journal of Engineering and Technology (IRJET) Volume: 04 Issue: 07 | July -2017.

8) Saurabh Kanungo, et.al, "Analysis Of A Tall Structure With X-Type Bracings Considering Seismic Load Using Analysis Tool Stadd.Pro,
International Journal Of Engineering Sciences \& Research Technology, 7(12): December, 2018.

9) Siva Naveen Ea,d et.al, " Analysis of Irregular Structures under Earthquake Loads" Science Direct Procedia Structural Integrity 14 (2019) 806-819.

10) Viswanath K.G et.al, "Seismic Analysis of Steel Braced Reinforced Concrete Frames", international journal of civil and structural engineering Volume 1, No 1, 2010.

11) IS 18932016 part 1 for Criteria for Earthquake resistant design of structure.

12) IS 19320 (Part 1) 2016

13) IS 456:2000

14) IS 875 part 1

15) IS 875 part 2

16) IS 875 part 3

17) IS 875 part 5 